\title{
POLITICAL THOUGHT OF THE POLISH SOCIALIST PARTY FORMER REVOLUTIONARY FACTION IN THE PERIOD OF 1928-1939
}

\begin{abstract}
The purpose of the article is to analyse the political thought of the Polish Socialist Party former Revolutionary Faction (PSPdFrRew) formed in 1928. The focus is primarily on the PSPdFR's attitude towards issues such as the state, economy, and democracy. The research utilised text analysis and document analysis methods. The results of the research found that the former PSP Revolutionary Faction proclaimed the principles of state socialism and used evolutionary methods to raise the standard of living of workers and introduced the Polish Socialist Republic. Although the PSP former Revolutionary Faction perceived its place in the broadly understood Sanation camp, it had negative attitudes towards the proposals of political, economic and social solutions of conservative and liberal representatives. Despite the oftendeclared attachment to democracy, the PSPdFR strongly criticised parliamentarism and proposed the introduction of strong arm rule.
\end{abstract}

Keywords: Polish Socialist Party Former Revolutionary Faction, political thought, Sanation Camp, Second Republic (1918-1939).

\section{INTRODUCTION}

Emerging in October 1928 from the Polish Socialist Party (PSP) a new political group called the Polish Socialist Party former Revolutionary Faction was a consequence of a number of processes taking place on the political scene of the Second Polish Republic, as well as internal processes developing within the PSP itself.

The issue that particularly affected the functioning of the PSP was the attitude of its activists to Józef Piłsudski. Even during the struggle for Poland's borders, the PSP was dominated by activists coming from the Revolutionary Faction led by J. Piłsudski during the partitions of the PSP. They decided on a patriotic direction in the party's activity, aimed at rebuilding and then defending the homeland against all existing threats, including against the Bolshevik invasion and communist ideology.

After this period, there was an outflow of Piłsudski activists from the party's structures. They broke with the PSP to join the military, administrative and political activities, submitting to J. Piłsudski himself. At the same time, new young activists, often with a pro-communist attitude, joined the ranks of the PSP.

\footnotetext{
${ }^{1}$ Adam Laska, PhD, Department of Security Sciences, Faculty of Management, Rzeszow University of Technology, Rzeszów al. Powstańców Warszawy 12; e-mail: alaska@prz.edu.pl. ORCID: 0000-0002-9777-3557.
} 
The main stronghold of Piłsudski's supporters in the PSP was the Warsaw organization of this party, headed by Rajmund Jaworowski. The Warsaw PSP organization was recognized as the best organized, most active and significant party structure, and the Workers' Militia organized within it, often in situations of unrest and political riots, turned out to be a real force influencing the development of the situation in Warsaw (Tymieniecka, 1982).

The activity of the Piłsudski group in PSP until May 1926 was part of the standard activity of a political group in which there are factions representing different directions within one ideology. The situation changed after the May coup. J. Piłsudski's rise to power through a coup d'état led to strong polarization in the PSP. On the one hand, the Warsaw organization of the PSP supported the activities of the coup instigators, and its members took part in military operations taking place on the streets of Warsaw. On the other hand, along with the activities of successive Sanation governments and J. Piłsudski himself, the PSP began to feel the need to move to sharp opposition.

Despite the growing conflict, a group of Piłsudski supporters in the PSP did not take action toward a split at the beginning. Together with the entire Polish Socialist Party, it joined the parliamentary elections in March 1928, suffering an electoral defeat in Warsaw. The situation was exacerbated with the outbreak of conflict in Warsaw trade union organizations associated with PSP. Warsaw activists, in opposition to the Central Committee of Trade Unions (KCZZ), a representative of class trade unions associated with the PSP, founded the Warsaw Trade Union Council, which caused loud protests from the leadership of the KCZZ and a call to suspend the membership rights of the activists responsible for these activities.

At the same time, the Pilsudski group in the PSP received tacit support from governmental factors. Under their auspices, on October 10, 1928, the Przedświt [Dawn] daily appeared, announced as a press body integrating the Polish socialist movement, which in the future became the main body of the secessionists.

The decisive struggle between the Piłsudski group led by Rajmund Jaworowski and the other members of the PSP Central Executive Committee (CKW) took place on October 17, 1928. Activists associated with the Piłsudski camp, and especially R. Jaworowski, were charged with conducting destructive activity in both the political and professional areas. An official request was also made for a definitive solution to the issue of the Warsaw District Workers' Committee of the Polish Socialist Party and the Warsaw Trade Union Council.

This led to the final decision to split and establish a new workers party under the name PSP former Revolutionary Faction. Its ranks were joined by, among others, Julian Smulikowski, Wacław Lenga, Zygmunt Gardecki, Zofia Praussowa, Medard Downarowicz, Tadeusz Szpotański, Adam Szczypiorski. PSPdFrRew branches were also established in Lublin (Marian Malinowski and the Mayor Antoni Pączek), in Kraków (Bobrowski), Silesia (Józef Biniszkiewicz), Łódź (Edmund Wieliński), and Częstochowa (Walenty Kałuża). A parliamentary club of PSPdFrRew with 10 deputies was also formed in the Sejm (Ajzner, 1972).

In general, they were closely related to J. Piłsudski and other leading Piłsudski supporters. Some of them were members of the former Combat Organization from the partitions, supporting and promoting these traditions. Jaworowski himself was a close friend of Walery Sławek standing from November 1927 at the head of the Sanation Partisan Bloc for Cooperation with the Government (BBWR).

In October 1928, the Central Association of Class Trade Unions (CZKZZ) was also established, i.e. a trade union headquarters ideologically associated with PSPdFrRew. Its 
management was formed by Zygmunt Gardecki (secretary general), Wacław Preis, Wojciech Wojciechowski, Józef Niski, Edmunt Morawski and Stanisław Celejewski, the press body of this trade union headquarters was the biweekly „Młot i Pług” [Hammer and Plough] published from February 1929 by M. Malinowski. In 1928, the CZKZZ had 34,000 members, after a year - mainly due to the absorption of small independent pro-government associations - already 97,000. The Association's branches operated in Łódź, Kielce, the Dąbrowski Basin, the Kraków Oil Basin, Płock, and Żyrardów, but mainly in Warsaw. The organization was dynamically developing in 1929-1930 to undergo another split related to the establishment of the Trade Union (Ajzner, 1972).

\section{IDEOLOGICAL GROUNDS FOR THE ACTIVITY OF THE POLISH SOCIALIST PARTY FORMER REVOLUTIONARY FACTION}

When analyzing the political thought of PSPdFrRew, it should be noted that the party's programming documents are not numerous and there is a need to rely primarily on press material and leaflets published on the occasion of the party's election and political campaigns (Program, 1933, Gliszczyńska, 1933).

The basic program document is the party program developed at the $21^{\text {st }}$ congress (the numbering of PSP congresses was preserved). It was a slightly modified version of the program of the Polish Socialist Party from 1920. The text changed the name of the party by adding membership of the former Revolutionary Faction, and several corrections were introduced as a result of changes in Polish political, economic and social life in the 1920-1928 period.

The party's program was preceded by an introduction presenting a brief historical outline of the development of the PSP with a strongly emphasized layer of the act of independence and the fight for Poland's freedom, which were often negated by various groups of far-left activists.

In the reborn homeland of PSPdFrRew, the main goal was to establish ,... the Polish Socialist Republic, made of all Polish territories, and with other Socialist Republics connected by nodes of permanent peace and brotherly cooperation" (Program, 1933).

In the economic and social area the Polish Socialist Republic created was to take over the ownership of the capitalists' means of production and communication (land, factories, mines, railways, shipping etc.). In the political area, it was to introduce changes in the functioning of the state to make it a ,body of the collective will of society”, which was identified with a change in social stratification (Program, 1933).

The evolutionary changes taking place in the capitalist system, which were claimed to be preparing the ground for socialism by creating a strong working class, were the way to achieve this goal. As stated at the time of development, with the unplanned capitalist economy there were numerous economic crises in which capitalism squandered the wealth it created and brought misery to workers. The increase in the size of the working class and its low standard of living was to create solidarity among workers and increase the awareness of the importance of this class in social life. The coexistence of the processes of growing contradictions in the capitalist system and the increase in the number and awareness of the proletariat would create a revolutionary situation enabling the realization of the ideals of socialism. The victorious social revolution was to enable socialist reconstruction of the economic, political and cultural life of nations (Program, 1933). 
This process had several conditions that could strengthen it, or slow it down or even stop it. Strengthening conditions included the awareness of the need to strongly organize the working class, the second factor was the need to cooperate with other social strata who suffered in capitalism and which could cooperate with the proletariat. Socialist activists were primarily concerned with a large group of white-collar workers and the rural population, mainly landless and small-farming. The awareness of internationalization of the working class struggle was also a strengthening factor. This allowed for the establishment of broad inter-state cooperation of workers, obtaining political and program support, and sometimes material support (A.K., 1931).

The resistance of capitalists and higher social classes to the changes proposed by the workers' movement was considered to be impeding. Fighting workers' legislation and the emergence and development of ideologies combating workers' aspirations or subordinating their aspirations to capitalists were recognized as its manifestation. As an example of ideologies combating socialism, first of all fascist movements were pointed out, which PSPdFrRew criticized from the beginning of its functioning. Later, this criticism also included national-socialist movements developing outside of Poland and within its borders (Laska, 2016). Solidarism and syndicalism were primarily recognized as ideologies that subordinate the aspirations of the working class capitalists (Laska, 2004).

The introduction of socialist rule, according to PSPdFrRew activists, could not take place against the will of the majority of society, hence the postulate of basing the functioning of the socialist state on democratic principles.

The consequence of this approach was the PSPdFrRew's rejection of the dictatorship of the proletariat, understood as the introduction of terror as a permanent system on the basis of which social reconstruction would be carried out. This solution was considered to be contrary to socialist principles and had no right to exist in the process of liberating the working class.

In the party press, when discussing the issue of party ideology, thinkers such as K. Marx, F. Engels, F. Lassalle or K. Kautsky were often referred to, but also Polish authors of socialist thought, such as K. Kelles-Krauz, W. Jodko-Narkiewicz or J. Piłsudski. R. Jaworowski himself published studies both on Piłsudski (Koryha, 1932) and Marx (Koryha, 1933) under the pseudonym Z. Koryha.

Despite the constant reference to revolutionary activities in press articles and political leaflets, it is difficult to consider the PSPdFrRew as a revolutionary party. Its program, and in particular a number of postulates related to the processes of postulated changes, places it among the reformist socialist parties. This is also evidenced by a departure from the principles of class struggle in relation to the role and form of the modern state.

PSPdFrRew ideologists recognized that the state is not a class institution, but a supraclass one, and therefore the pursuit of socialism should be implemented by gaining influence in all institutions of this state from the Sejm, through local government institutions, as well as in organizations of economic life (Tomasiewicz, 2012).

\section{THE ECONOMIC PROGRAM OF THE POLISH SOCIALIST PARTY FORMER REVOLUTIONARY FACTION}

According to PSPdFrRew ideologists, the socialization of economic life was to be the way to introduce socialism. It was to take place through the evolutionary mastery of the 
state institutions of both state and local government authorities as well as economic institutions. Such a solution was to enable the working class to have the greatest influence on the state's activity.

The PSPdFrRew economic program included a number of postulates whose implementation was to improve the life of the working class. These included: labor protection, in particular compliance with a maximum 8-hour working day at most, and a 46-hour work week and Sunday rest - this demand was changed at the time of economic crisis to a request for a 6-hour day and a 36-hour work week - paid holiday leave for all workers and employees, prohibition of child labor, reduction of night work, introduction and care of sanitary regulations regarding health of workplaces and prevention of accidents at work, equal pay for both sexes for equal work, state insurance of workers and employees against illness, accidents, unemployment and old age. Securing widows and orphans, freedom of strikes and professional workers' organizations.

It was also postulated to socialize mature industries, especially mines of all kinds, foundries and means of communication. Socialization in the form of communal ownership of enterprises serving the needs of the general population of the municipality, such as power plants, gas plants, trams, pharmacies, bakeries, slaughterhouses, residential houses. State monopoly on trade in basic necessities. Municipalities, together with consumer cooperatives, take over the distribution of necessities. State support for consumer cooperatives. Nationalization of banks. Nationalization of forests and waters. Expropriation of larger agricultural property, leaving part of the expropriated land for the state and municipal economy, with the remaining part leased to non-farming and low-income companies and families as well as workers' cooperatives.

The ideology of the PSP former Revolutionary Faction was thoroughly evolutionary. According to party theorists, the development of the modern economy inevitably led to „state socialism," in which the state not only engages directly in the economy, but also controls the private sector. Based on this assumption, party ideologists proclaimed that in order to socialize the tools of work, all measures aimed at developing the country's productive forces should be supported. It was emphasized, however, that the working class was not yet prepared to take control of production, so current policy was limited to defending social gains and fighting for higher wages. The recognition of the central role of the state in the work of socio-economic transformations was, in fact, secondary to the deep-rooted belief that the idea of Polish socialism is inseparably connected with the building of Polish independence.

\section{THE ATTITUDE OF THE POLISH SOCIALIST PARTY FORMER REVOLUTIONARY FRACTION TO THE SYSTEM OF SANATION GOVERNMENTS AND DEMOCRACY}

While the ideological assumptions and postulate for the creation of the Polish Socialist Republic were contrary to the objectives and practice of the Sanation camp governments, the foundations of the economic program and the pro-state policy pursued by the PSPdFrRew also allowed the designation of common points with the ruling camp. This happened despite the strong rejection by PSPdFrRew activists of the accusations of other socialists that they had become so-called Non-party Socialists (abbreviated as BBSs).

Considering in a broader context the aspirations of the socialist parties, PSPdFrRew stated ,There is no gap between the maximum program and the minimum program. It is 
only at a slower or faster pace, depending on the conditions, getting brick by brick, a great edifice that liberates humanity, is today a gradual transition from one life form to another". That is why PSPdFrRew's cooperation with the Sanation camp was also explained by achieving greater effectiveness in implementing the socialist program. According to the leaders of this party, it was better to implement socialist reforms in small steps under the Non-partisan Bloc for Cooperation with the Government (BBWR), making workers' lives more tolerable than remaining in ruthless opposition and depriving themselves of „,causative power" as other socialist parties did.

Defining the attitude towards the party in power, PSPdFrRew activists stated:

„Our attitude towards Sanation and its parties is clear (...) the PSP former Revolutionary Faction is a socialist party, standing in a class struggle in the name of freeing the working-class masses of Poland from the bondage of capitalist exploitation (...) The Block of Cooperation with the Government (...) negates class struggle and the socialist system, proclaiming social solidarity, i.e. the so-called agreement of all social strata in the name of some supra-class ideal of abstract statehood. (...) Life itself gives the lie to these solidarist theories, picked up by Sanation groups, theories that have long passed and have gone completely bankrupt. Social development is a constant class struggle between capital and work. Social solidarity, or class solidarity, is a product of bourgeois thought, seeking salvation from the coming victory of socialist thought, from a new system that is irrevocably and consistently approaching to replace the often invisible and imperceptibly collapsing capitalist system. Products of sanation from the sign of the Federation of Labor are only ephemeris, whose life is briefly calculated. It does not matter what theory these Sanation associations created by the Federation of Labor adhere to: syndicalist or solidarist. The labor movement throughout the world has consolidated its existence in the working masses and facilitated its struggle by adopting a class platform" (Rozłam, 1928).

However, this ideological conflict often disappeared in the situation of real political choices made by PSPdFrRew. This particularly concerned the area of basic values that were considered the most important by Piłsudski. They were associated with the functioning of the independent Polish state, which was understood as an entity with an ontological status, not requiring any justification, obliged by history to achieve the greatness and purpose of all of the political activities of its inhabitants.

The recognition of the state, not the nation, as the chief value by Piłsudski distinguished the Polish variant of authoritarianism as a political system and determined views on other values and political goals set. The above-mentioned arrangements justified Piłsudski's postulate of a reverse state-society relationship model - this state was to harmonize the interests of individuals and all social, political and ethnic groups, to combine them in a joint effort for the common good (Paruch, 2014).

The relationship between PSPdFrRew and J. Piłsudski, which was still the main reference point for PSPdFrRew's activity, proved to be permanent. In the mid-1930s, in one of the articles we can read a peculiar auto da fe of a party member regarding his attitude towards J. Piłsudski: 
„We continue to fight relentlessly for the traditions of Piłsudski's life, the traditions of the real PIŁSUDSKI, we organize in a flood of Piłsudski supporters - REAL PIŁSUDSKI. We continue to organize persistently the true PIŁSUDSKI: left, radical, socialist - and revolutionary. And we fight for true tradition and the true face of ZIUK General Piłsudski!" (Koryha, 1932).

The PSPdFrRew had an equally uncritical attitude towards the May Coup itself, or rather the „May Revolution” as it was called. Every year on May 12, articles indicating the historical significance of this act in Polish history were published in the party press. However, the situation was different with the political organizations of the Sanation camp. PSPdFrRew constantly criticized both the activities of the BBWR and the trade union centers associated with it. The vast majority of decisions in the area of economic and social policy were also criticized, characterized as anti-labor activities and induced by capitalist spheres, wanting to resolve the acute economic crisis by restrictions on workers' rights.

Considering the May events of 1926 as the second most important date in the history of reborn Poland, just after August 1920, it raised a natural question about the place of democracy in the ideology of PSPdFrRew. Support for J. Piłsudski's assassination would indicate at least a critical attitude of the PSPdFrRew ideologists towards the democratic system. However, they saw this issue slightly differently. As it was stated:

„When anyone seriously wants to think about the issues of democracy and its threat in Poland, they must first and foremost separate the issues of democratic forms of society and democratism of the society as carefully as possible. Without this, there can be no fair discussion in this regard. Democracy in Poland will always remain »in danger « until Poland becomes a democracy in all its national and social content, and not only in the name and forms of the system" (Demagogia, 1928).

What caused the biggest opposition of the PSPdFrRew to democratic forms of government was their weakness in the face of the challenges that Poland faced after regaining independence. Democratic institutions were accused of not being able to create stable governance in the country and a lack of effectiveness in actions directed against anti-democratic forces. PSPdFrRew activists were convinced of the impossibility of creating strong and effective democratic institutions that would ensure the authority and respect of the state without democratizing the whole of society. In their opinion, constant threats to democracy were not only a Polish issue. As they stated, only Switzerland could be considered a democracy in its entire national and social content, and only Switzerland could boast of a democracy functioning without threats elsewhere. In their opinion, all other democratic systems of countries of the world were exposed to the danger of being overthrown by anti-democratic factors and tendencies.

When asked when the danger of the overthrow of democracy in Poland, i.e. the forms of democratic system and the possibility of working on democratizing content, was greater - before or after the May revolution, the ideologists of the PSPdFrRew clearly advocated the latter option.

For PSPdFrRew ideologists democratizing society meant not only giving it freedom, but also responsibility for the state. Hence, the main methods of democratizing society were all 
activities involving society in the state management process, which included primarily direct democracy and all forms of local government. Such a conscious and organized society still needed stable state power. Therefore, PSPdFrRew postulated the introduction of strong presidential power, deposited in the hands of a person elected in general elections, giving the strongest legitimacy to exercise power. It was recognized that the stronger the individual exercised this power, the greater the likelihood of healing democracy in the state. In the activities of such an entity, taking into account the demands of the working class, a socialist system could be introduced.

Describing the tasks that the PSPdFrRew carried out in the political situation of Poland after 1928, it was stated: ,The interest of socialism, development and power of the Republic requires (...) that a gap should not be dug between Piłsudski and the working class. PSPdFrRew is counteracting this gap" (Nasza, 1931).

At the same time, there was a sphere of state activity that was always met with favorable reception by PSPdFrRew politicians. This was the government's foreign policy. Every fact of the increase of Poland's international significance and its security was received with great understanding and recognition.

International issues of particular interest to PSPdFrRew were relations with Poland's direct neighbors, i.e. the Soviet Union and Germany. Both of these countries were considered hostile to Poland, so the search for solutions aimed at securing the security of the Polish state was a constant concern. Attitude to Soviet Russia was derived from three issues. First, official relations between the two countries, where the best political and economic relations were demanded. Secondly, the situation in Soviet Russia itself, where the development of the Stalinist system was observed with concern. Thirdly, the perception of Soviet Russia as a promoter of the communist movement in Poland, which was very negatively assessed, demanding that the communist party be combated and its influence minimized.

At the beginning of the 1930s, PSPdFrRew drew attention to the huge international threat associated with the development of Nazi ideology in Germany. Hitlerism and fascism became for PSPdFrRew the main focus of criticism, and the progress of these ideologies in Europe was carefully noted and criticized by the party press.

\section{CONCLUSION}

After 1926, the Sanation camp in Poland attempted to establish a movement that was to be a political base for the rulers, but with a heterogeneous arrangement, because it had to correspond to the balance of power within society. Despite the clear ideological identity, the camp was to be a political entity bringing together many groups and environments of different program orientation.

The leaders of the Piłsudski formation wanted to have „their own” conservatives, liberals, radicals, people's and socialists, and even nationalists. This goal could only be achieved as a result of the deliberate decomposition of the political system in the Polish-Lithuanian Commonwealth and its individual segments (left, center, right and „minority”) after the May coup. The Polish Socialist Party former Revolutionary Faction was an example of such a political formation. Its activists wanted to be representatives of socialist thought and democracy, at the same time accepting the anti-democratic practice proper to Sanation governments and the anti-democratic system solutions used after the May coup, as well as participating in the authoritarian management of the state (Paruch, 2005). 
By maintaining their organizational independence and repeatedly criticizing those in power for their anti-worker activities, they did not have much influence on the sphere of decision-making elite of the Sanation camp. Despite this, until 1935 they fully implemented the policy of J. Piłsudski, constituting one of the components of the ruling camp.

\section{REFERENCES}

Ajznar, S. (1979). Związek Zwiąków Zawodowych 1931-1939. Warszawa.

A.K. (1931). Walka o socjalizm. ,Walka”, nr 30.

Gliszczyńska, S. (1933). Pierwszy maja. Warszawa.

Jaworowska, K., Wspomnienia o Rajmundzie Jaworowskim i jego pracy, AAN, Spuścizna Konstancji Jaworowskiej, sygn. 330 IV-1.

Koryha, Z. (R. Jaworowski) (1932). Józef Pitsudski. „Walka”, nr 79.

Koryha, Z. (R. Jaworowski) (1933). Karol Marks. Warszawa.

Laska, A. (2004). Narodowa Partia Robotnicza 1920-1937. Studia z dziejów ruchów społecznych w Drugiej Rzeczypospolitej. Rzeszów.

Laska, A. (2016). National-socialist groups in Poland in the period 1918-1939, 3rd International Multidisciplinary Scientific Conference on Social Sciences and Arts SGEM, Book 3, Vol. 2.

Nasza taktyka (1931). ,Walka”, nr 4.

Paruch, W. (2014). Myśl polityczna formacji pitsudczykowskiej w Polsce (1926-1939) - cechy podstawowe. Annales Universitatis Mariae Curie-Skłodowska Lublin-Polonia, Vol. XXI.

Paruch, W. (2005). Myśl polityczna obozu piłsudczykowskiego 1926-1939. Lublin.

Program Polskiej Partii Socjalistycznej dawnej Frakcji Rewolucyjnej uchwalony na XXI Kongresie w Katowicach (1933). Warszawa.

Rozłam w PSP (1928). Warszawa.

Tomasiewicz, J. (2012). Naprawa czy zniszczenie demokracji? Tendencje autorytarne i profaszystowskie w polskiej myśli politycznej 1921-1935. Katowice.

DOI: $10.7862 /$ rz.2019.hss.39

The text was submitted to the editorial office: November 2019.

The text was accepted for publication: December 2019. 
